\title{
SOLUBILIZATION OF POTASSIUM FROM ALTERNATIVE ROCKS BY HUMIC AND CITRIC ACIDS AND COFFEE HUSK
}

\author{
Solubilização de fontes alternativas de potássio pelos ácidos húmico e cítrico e casca de café
}

\author{
Rodrigo Souza Pessoa ${ }^{1}$, Carlos Alberto Silva ${ }^{1}$, Bruno Silva Moretti ${ }^{1}$, \\ Antônio Eduardo Furtini Neto ${ }^{2}$, Alberto Vasconcellos Inda ${ }^{3}$, Nilton Curi ${ }^{4}$
}

\begin{abstract}
Brazil imports most of the potassium that it consumes in agriculture, however, such huge external dependence can be minimized with the use of alternative local $\mathrm{K}$ bearing rocks. This experiment was conducted with the objective of evaluating the solubility of nepheline syenite and glauconite as a function of three organic matrices, humic acid, citric acid and coffee husk. Incubation of low grade $\mathrm{K}$ rocks and organic matrices were done in laboratory conditions, in a completely randomized design. Each rock was mixed with five different doses of each organic matrix and the potassium solubilized was measured periodically, during 180 days. Regardless of the organic matrix and its dose investigated, nepheline syenite samples released more K than the modified glauconite. Soluble K increased as the incubation time increased and its release was greater as the organic matrix dose increased. There was more soluble $\mathrm{K}$ when the coffee husk was mixed with the potassic rocks, in relation to the humic and citric acids.
\end{abstract}

Index terms: Low grade K rocks; alternative source of K; rock weathering; organic matrices.

\section{RESUMO}

O Brasil importa mais de $90 \%$ de todo o potássio que consome na agricultura, todavia, essa importação pode ser minimizada com a utilização de fontes alternativas de potássio disponíveis no país. Nesse contexto, conduziu-se um experimento com o objetivo de avaliar a solubilidade das rochas sienito nefelínico e glauconita em função do emprego de três diferentes matrizes orgânicas: ácidos húmico, ácido cítrico e casca de café. O experimento foi realizado em laboratório, sendo adotado o delineamento inteiramente casualizado. Cada rocha foi misturada com cinco doses diferentes de cada matriz orgânica e as avaliações dos teores de K solubilizado foram realizadas, periodicamente, durante 180 dias. O teor de potássio solúvel foi determinado em função do emprego de solução de ácido cítrico a $2 \%$ e água, na fase de extração. Independentemente da matriz orgânica e de sua dose, o sienito nefelínico libera mais K que a glauconita. O K solubilizado aumenta com o acréscimo do tempo de incubação e sua liberação é maior, à medida que se eleva a dose da matriz orgânica. Há maior solubilização de K quando a palha de café é misturada às rochas potássicas em relação aos ácidos húmico e cítrico.

Termos para indexação: Rocha potássica de baixo valor agronômico; fonte alternativa de K; degradação de rochas; matrizes orgânicas.

\section{INTRODUCTION}

In Brazil, around $92 \%$ of the potassium used in agriculture is imported (Nascimento; Loureiro, 2008). Since Brazil is highly dependent on external $\mathrm{K}$ fertilizers, the search for alternative $\mathrm{K}$ sources is becoming increasingly a matter of national security. According to recent studies, national reserves of commercially available materials are on the verge of depletion (Nascimento; Loureiro 2008), which further increases the need for new research into technologies to minimize the reliance upon on imported potassium. In Brazil, $\mathrm{K}$ imports are necessary because, currently, the national production is not capable of meeting the demand and most of the Brazilian potassic rocks have a low K concentration and solubility (Theodoro et al., 2006). Brazil needs imported fertilizers, however, part of the $\mathrm{K}$ demand can be supplied by alternative rocks (Straaten, 2006), if their agronomic efficiency is increased and low cost solubilization processes are figured out to formulate $\mathrm{K}$ biofertilizers with high use efficiency by plants.

In the Minas Gerais state, nepheline syenite and modified glauconite are the two rocks which stand out as having potential for use as $\mathrm{K}$ fertilizer. Nepheline syenite is a rock composed mainly of microcline, orthoclase,

${ }^{1}$ Universidade Federal de Lavras/UFLA - Departamento de Ciência do Solo/DCS - Lavras - MG - Brasil

${ }^{2}$ Instituto Tecnológico Vale/ITV - Vale S. A. - Belém - PA - Brasil

3Universidade Federal do Rio Grande do Sul/UFRGS - Faculdade de Arquitetura/FA - Departamento de Solos - Porto Alegre - Rio Grande do Sul - RS - Brasil

${ }^{4}$ Universidade Federal de Lavras/UFLA - Departamento de Ciência do Solo/DCS - Cx. P. 3037 - 37200-000 - Lavras - MG - Brasil - niltcuri@dcs.ufla.br

Received in july 8, 2015 and approved in july 21, 2015 
andesine and nepheline; it has approximately $9 \%$ of $\mathrm{K}_{2} \mathrm{O}$ (Andrade et al., 2005), and the modified glauconite is a rock of metasedimentary origin which has a $\mathrm{K}_{2} \mathrm{O}$ content ranging from 6 to $14 \%$, showing the agronomic value of this rock to fertilize crop fields (Piza et al., 2011; Silva et al., 2012a; Silva et al., 2012b). Its mineralogy encloses glauconite, recrystallized quartz, light brown clay matrix, kaolinite and micas, such as muscovite, biotite and chlorite (Silva et al., 2012b).

Due to their mineralogical compositions, both nepheline syenite and modified glauconite have low soluble $\mathrm{K}$ contents. However, in an acidic medium, there is a tendency to increase the K solubility (Teixeira et al., 2012). Thus, the use of acid producing organic compounds in a mixture with these rocks could increase the solubility of $\mathrm{K}$, with a consequent increase in the available $\mathrm{K}$ contents after incubation. Such increase in K solubilization is due to the action of organic acids released during the decomposition of organic matter or added directly, as in a mixture of rock with citric acid (Baldotto et al., 2011). Several studies have been conducted with the objective of evaluating the efficiency of organic compounds in the solubilization of nutrients in rocks. Compounds in animals' manure (Abbasi et al., 2015); (Alloush, 2003), plant residues (Adesanwo et al., 2012) and a mixture of potassium rock in composting (Saleem; Arshad; Yaseen, 2013) has provided relevant increases in K solubility. Increase in rock solubility is related to the activity of microbes that lower the $\mathrm{pH}$ by liberating organic acids or organic ligands with a high ability to chelate cations (Liu et al., 2011; Chen, 2000). As there is an organic matrix mixed with the rock, there is the possibility of the biofertilizer produced to have other beneficial functions in soil and plants, since it contains humic substances mixed with the $\mathrm{K}$ supplied to plants.

Studies using coffee husk in rock solubilization have reported several advantages, such as the medium to high total $\mathrm{K}$ found in the coffee residue and the recycling of the huge amounts of coffee husk produced in the Brazilian coffee fields (Higashikawa; Silva; Bettiol, 2010). Coffee husk wastes, if not properly used, may become an environmental problem, if it is not discharged correctly (Zoca et al., 2014). When used in composting piles, coffee husk, whose total $\mathrm{K}$ levels are variables among husks, ranging from 23 to $49 \mathrm{~g} \mathrm{~kg}^{-1}$ (Zoca et al., 2014; Higashikawa; Silva; Bettiol, 2010) may, increase the low concentrations of $\mathrm{K}$ already present in the Brazilian low grade rocks. In Brazilian coffee fields, about 45 million bags of processed coffee grain are produced each year (Companhia Nacional de Abastecimento - CONAB, 2015).
It is speculated that the coffee husk may play an important role in increasing the solubilization of $\mathrm{K}$ rocks, by lowering the $\mathrm{pH}$ of the medium, providing organic ligands or chelating cations present in the structure of the $\mathrm{K}$ rocks, resembling mechanisms already discussed in other studies (Liu et al., 2011; Lopes-Assad et al., 2010; Straaten, 2006). Citric acid may be even a more effective in weathering the $\mathrm{K}$ rocks, due to the acidic nature and high ability of this tri-carboxylic acid in complexing $\mathrm{K}$ and other cations. Little is known about the role played by humic acid as a solubilizing agent, though this fraction is characterized by a high capacity to complex and chelate cations, and high acidic content (Stevenson, 2004); humic acid may assure also a good environment for organisms directly acting on rock degradation. In this context, the objective of this study was to evaluate the release of soluble $\mathrm{K}$ from nepheline syenite and modified glauconite incubated and composted with coffee husk, citric and humic acids. Released K was evaluated at different sampling times, since the incubation period extended to 180 days.

\section{MATERIAL AND METHODS}

The work was conducted at the Soil Fertility laboratory, Soil Science Department/Federal University of Lavras (UFLA), Lavras-MG, from November 2013 to September 2014. Two potassic rocks were used for the study, the first was classified as a nepheline syenite, commonly found in the Poços de Caldas municipality, MG; the second rock was characterized as a modified glauconite, extracted in the region of São Gotardo-MG.

Modified glauconite samples were prepared by crushing them in a jaw crusher and grinding in a ball rotating mill. Next, the powder material was sieved using a 150 mesh sieve $(0.105 \mathrm{~mm})$ (Ministério da Agricultura, Pecuária e Abastecimento - Mapa, 2007). Rock mineralogical characterization was performed using the X-ray diffraction (XRD), and the powder and oriented blade routines, according to the principle of Bragg's Law, detailed below.

A Synth ${ }^{\circledR}$ manufactured p.a. granulated citric acid (molecular formula: $\mathrm{C}_{6} \mathrm{H}_{8} \mathrm{O}_{7}$, molecular weight of 192.12 , water solubility of $60 \mathrm{~g} / 100 \mathrm{ml}$ at $20^{\circ} \mathrm{C}$ and purity of $99.5 \%$ ) was used in this study. A commercial humic acid with $40 \% \mathrm{C}$ and extracted from secondary reserves of mineral coal (Australian leonardite) was the humic matrix mixed with the low grade $\mathrm{K}$ rocks. The coffee husk sample with $5.6 \%$ total $\mathrm{K}_{2} \mathrm{O}$ was provided by the UFLA farm. 
As a manner of standardizing the final particle size for each treatment, the organic matrices were dried and milled to pass a 150 mesh sieve.

The experiment was composed of six mixtures of $\mathrm{K}$ rocks, glauconite $(\mathrm{G})$ and nepheline syenite $(\mathrm{S})$, with the following organic matrices: Coffee Husk (CC), Citric Acid (AC) and Humic Acid (HA). The mixtures (w/w) were characterized as the following treatments: $\mathrm{S}+\mathrm{CC}$; $\mathrm{S}+\mathrm{AC}$; $\mathrm{S}+\mathrm{AH}$ and $\mathrm{G}+\mathrm{CC} ; \mathrm{G}+\mathrm{AC} ; \mathrm{G}+\mathrm{AH}$. Each experimental unit was made up of $150 \mathrm{~g} \mathrm{~K}$ rock-organic matrix mixture, for each rate of the organic matrix incubated with $\mathrm{K}$ rock. Coffee husk was mixed with the two low grade $\mathrm{K}$ rocks in the following doses: 0, 5, 10, 20 and 40\% (w/w). Citric and and humic acid were mixed with the modified glauconite and syenite samples in the following doses: $0,1,2,5$ and $10 \%(\mathrm{w} / \mathrm{w})$.

The total $\mathrm{K}_{2} \mathrm{O}$ content in the organic matrices was determined using the nitric-perchloric acid digestion procedure, in which $1 \mathrm{~g}$ of humic acid and citric acid was weighed and transferred into a digestion tube; in sequence, $6 \mathrm{ml}$ of concentrated $\mathrm{HNO}_{3}$ (nitric acid) were added to each tube and left at rest in a hood for 24 hours. After the rest period, each tube was shaken by hand for 10 seconds, before the digestion phase. Organic matrices were heated to a temperature of $80^{\circ} \mathrm{C}$ for $1 / 2$ hour; next, the temperature was increased to $120{ }^{\circ} \mathrm{C}$ until 0.5 to $1 \mathrm{ml}$ of digested extract remained in the tubes. After this procedure, $1 \mathrm{ml}$ of concentrated $\mathrm{HClO}_{4}$ (perchloric acid) was added to each tube, and, again, the material was heated at the temperature of 180 to $190^{\circ} \mathrm{C}$. Samples were kept at this temperature for 2 hours; in sequence, about $20 \mathrm{ml}$ of distilled water were added and the material transferred to a $50 \mathrm{ml}$ volumetric flask, and, again, the volume was completed with distilled water (Mapa, 2007). Total content of $\mathrm{K}_{2} \mathrm{O}$ in the investigated humic acid was $8.5 \%$, whereas, citric in acid no $\mathrm{K}$ was found in its composition. Coffee husk sample used in this study has a $\mathrm{K}_{2} \mathrm{O}$ content of $5.6 \%$, when the nitro-perchloric digestion method is employed (Higashikawa; Silva; Bettiol, 2010).

Each experimental unit was composed by $250 \mathrm{ml}$ plastic containers filled with the different combinations of the two low grade $\mathrm{K}$ rocks and organic matrix rates. Potassium rocks-organic matrixes mixtures were incubated during a 180-day period. At the incubation times of $0,7,15$, $30,75,120$ and 180 days, a $3 \mathrm{~g}$ subsample was taken and dried in an oven at $65^{\circ} \mathrm{C}$ for 24 hours in order to quantify the concentrations of $\mathrm{K}$ solubilized. Determination of soluble $\mathrm{K}$ was performed using both water and a $2 \%$ citric acid solution as extractants. During the incubation period, water content of the mixtures investigated was kept close do $70 \%$ of the maximum water retention of each mixture of $\mathrm{K}$ rock and organic matrix tested.
For $\mathrm{K}_{2} \mathrm{O}$ determination in water, a $0.5 \mathrm{~g}$ of sample was weighed and transferred to a 125 -ml Erlenmeyer flask and $100 \mathrm{ml}$ distilled water was added. The containers were heated on a hot plate until boiling, for 10 minutes. After cooling to room temperature, the solution was filtered, by using a medium filter paper. After complete filtration of the solution, the digested material was analyzed on a flame spectrophotometer to quantify K content (Mapa, 2007).

Extraction of $\mathrm{K}_{2} \mathrm{O}$ in a $2 \%$ citric acid was done in a $1 \mathrm{~g}$ sample of each replicate in a $125 \mathrm{ml}$ Erlenmeyer flask, where $100 \mathrm{ml}$ of $2 \%$ citric acid solution was added in sequence. The Erlenmeyer flasks with the solution were shaking at $203 \mathrm{rpm}$ for 30 minutes. After the shaking step, the solution was filtered in a medium filter paper. Fifty $\mathrm{ml}$ of each solution were collected and $\mathrm{K}$ was determined by flame spectrophotometer and converted to $\mathrm{K}_{2} \mathrm{O}$ (Mapa, 2007).

Low grade $\mathrm{K}$ rocks were mineralogically characterized with X-ray diffraction (XRD) on a Bruker-D2 Phaser machine (Cu tube with Ni filter, LynxEye ${ }^{\circledR}$ detector and a $0.3 \mathrm{~mm}$ primary slit operated at $30 \mathrm{kV}$ and $15 \mathrm{~mA}$ ). The slides were filled with material finely ground in an agate mortar without orientation (in powder) and analyzed in the range of 4 to $70^{\circ} 2 \theta$ at an angular speed of $0.02^{\circ} 2 \theta / \mathrm{s}$ with a reading time of 0.5 second per step. The qualitative interpretation of spectrum was made by comparison with standards contained in the PDF02 database (ICDD, 2006) of the Bruker DiffracPlus software. The analyses showed that the mineralogical composition of nepheline syenite was mainly related to microcline, orthoclase, andesine and nepheline minerals (Figure 1).

The mineralogy of glauconite was associated mainly with glauconite, quartz, chlorite serpentine and illite minerals (Figure 2).

Each mixture of the $\mathrm{K}$ rocks and organic matrices was incubated and characterized previously in relation to the $\mathrm{K}_{2} \mathrm{O}$ content, by using the nitric-perchloric acid digestion method for the organic matrices and the perchloric acid, sulfuric acid, acqua regia and nitricperchloric methods to evaluate the $\mathrm{K}$ contents in the two low grade rocks (Table 1) (Mapa, 2007).

The experimental design was completely randomized with three replications. Results obtained were submitted to the analysis of variance and regression, when necessary. The contents of $\mathrm{K}_{2} \mathrm{O}$ extracted with citric acid solution and water, for each mixture incubated, were plotted against the incubation time, in days. The treatment means were compared by the Tukey test $(\mathrm{p}<0.05)$ and, for some data, the regression analysis was performed. All the statistical procedures were performed using the SISVAR $5.3^{\circledR}$ software (Ferreira, 2011). 


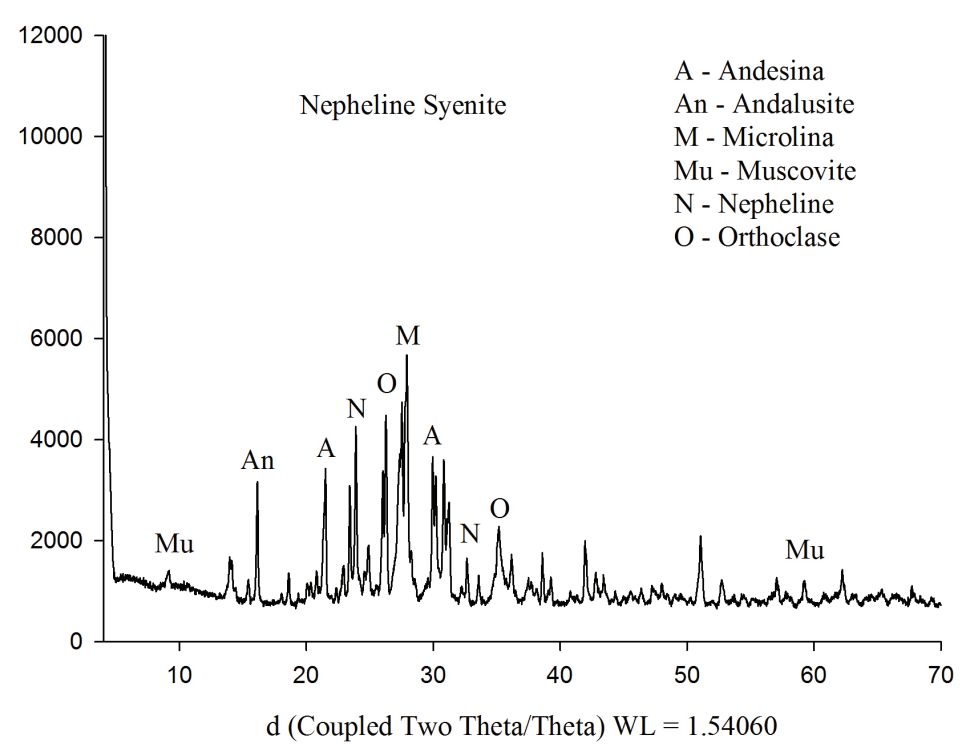

Figure 1: X-ray diffraction of the nepheline syenite rock with its respective identified minerals.

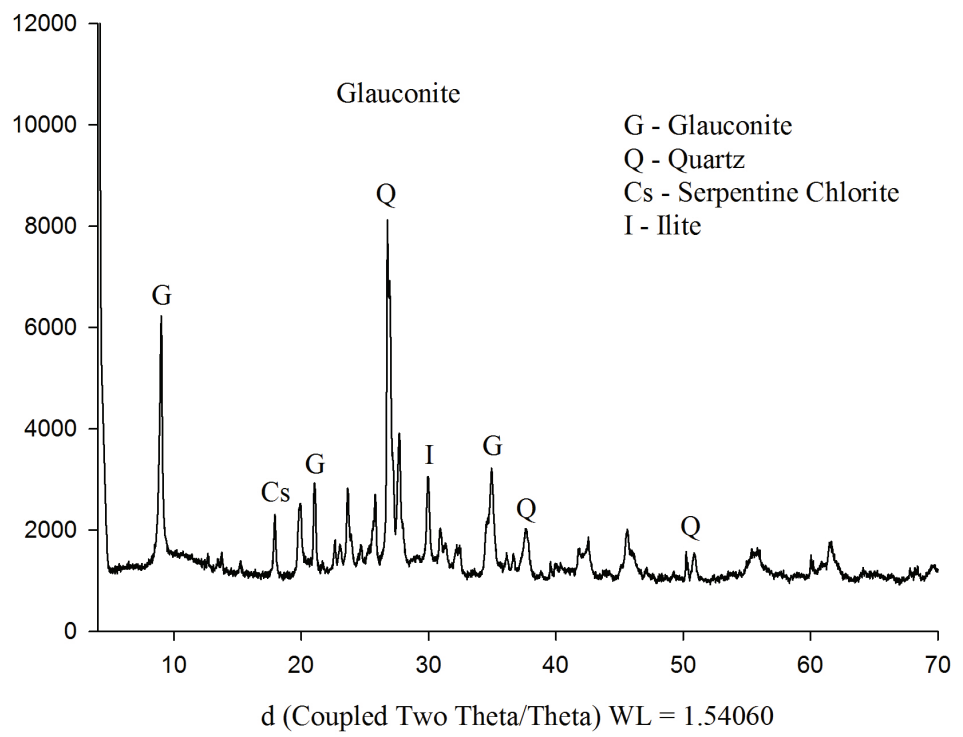

Figure 2: X-ray diffraction of the modified glauconite rock and its respective identified minerals.

Table 1: Potassium contents in the nepheline syenite and glauconite rock samples, according to perchloric acid, sulfuric acid, acqua regia and nitric-perchloric digestion procedures, following analytical methods described in Mapa (2007).

\begin{tabular}{ccccc}
\hline K rock & Perchloric acid & Sulfuric acid & Acqua regia & Nitric-perchloric \\
\hline Nepheline syenite & 1.6 & ---------- & 1.7 \\
Modified glauconite & 2.5 & 3.3 & 1.1 & 2.3 \\
\hline
\end{tabular}

Ciênc. Agrotec., Lavras, v. 39, n. 6, p. 553-564, nov./dez., 2015 


\section{RESULTS AND DISCUSSION}

\section{Nepheline syenite solubilization}

In general, it was found a significant increase in the solubility of potassium from nepheline syenite over time when coffee husk was mixed with this $\mathrm{K}$ low grade rock (Figure 3). Treatments that received the greatest doses of coffee husk provided a greater release of potassium in both citric acid solution and in water extractions. A quadratic model was the one which best fit the data relating the levels of soluble $\mathrm{K}$ over incubation time, when the coffee husk was added in the $40 \%$ dose. For other treatments, a linear model was fited to the increased levels of soluble $\mathrm{K}$ versus incubation time (Table 2).

Effect of time on the soluble potassium content was observed with greater intensity for the treatments that received the dose of $40 \%$ coffee husk, which was probably related to the greater organic matter content in this specific treatment. As the rate of organic matter decomposition is increased, there is a greater proliferation of microorganisms that enhances the release of acidic chemical species to the medium, which accelerates the degradation of the rock and solubilization of $\mathrm{K}$ (Liu et al., 2011). There is also more $\mathrm{K}$ in coffee husk as the dose of this postharvest coffee residue is increased.

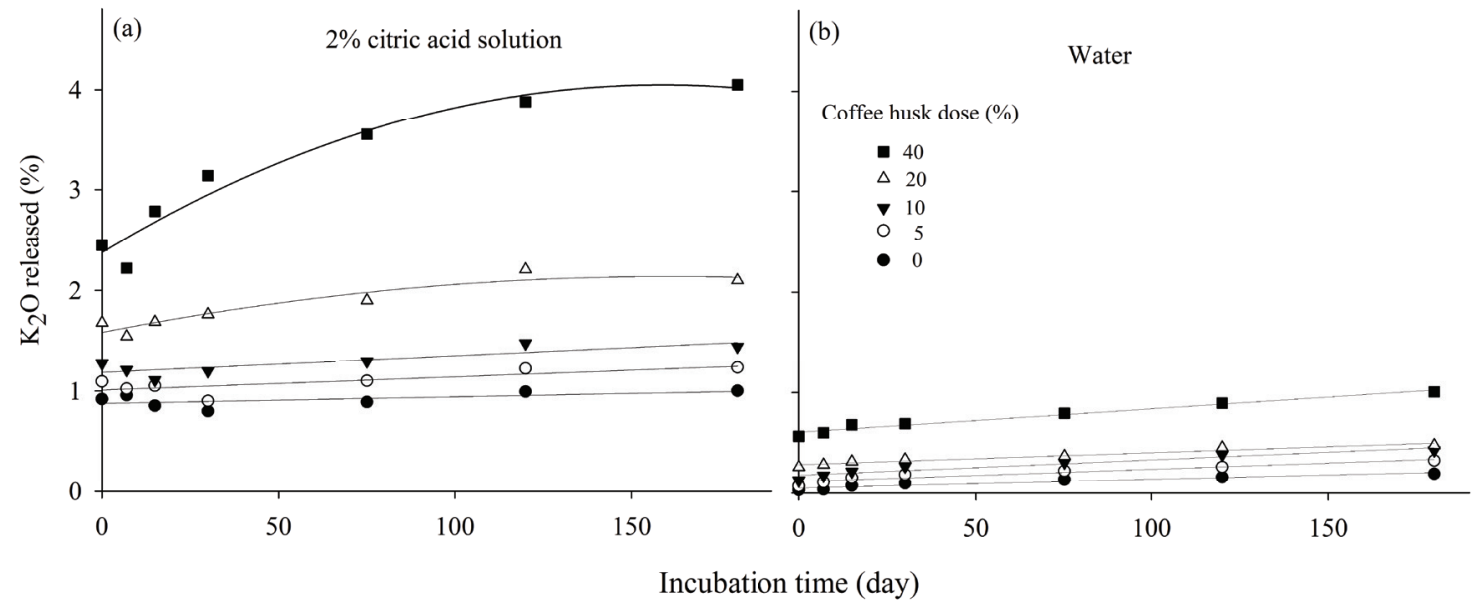

Figure 3: Potassium released by the nepheline syenite samples over time as a function of coffee husk dose, with $\mathrm{K}$ extraction in: (a) citric acid solution, and (b) water.

Table 2: Mathematical equations fitted to the $\mathrm{K}$ released over time as a function of coffee husk dose and $\mathrm{K}$ extraction by the citric acid solution and water.

\begin{tabular}{|c|c|c|c|c|}
\hline \multirow{6}{*}{ 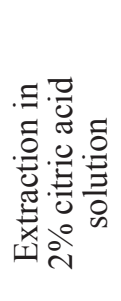 } & Figure & Coffee husk dose $(\%)$ & Equation & $\mathrm{R}^{2^{* *}}$ \\
\hline & $3 a$ & 0 & $\mathrm{y}=0.000836^{*} \mathrm{x}+0.88$ & 0.39 \\
\hline & $3 a$ & 5 & $\mathrm{y}=0.001358 * \mathrm{x}+1.01$ & 0.61 \\
\hline & $3 a$ & 10 & $\mathrm{y}=0.001645 * \mathrm{x}+1.19$ & 0.71 \\
\hline & $3 a$ & 20 & $y=-0.000021 * x^{2}+0.0069 * x+1.58$ & 0.90 \\
\hline & $3 a$ & 40 & $y=-0.000054 * x^{2}+0.0156 * x+2.61$ & 0.42 \\
\hline \multirow{5}{*}{ 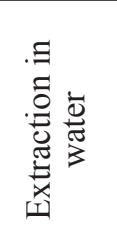 } & $3 b$ & 0 & $\mathrm{y}=0,005250 * \mathrm{x}+0.0135$ & 0.99 \\
\hline & $3 b$ & 5 & $\mathrm{y}=0,029333 * \mathrm{x}+0.0139$ & 0.99 \\
\hline & $3 b$ & 10 & $y=0,060750 * x+0.0149$ & 0.99 \\
\hline & $3 b$ & 20 & $\mathrm{y}=0,098417 * x+0.0143$ & 0.98 \\
\hline & $3 b$ & 40 & $\mathrm{y}=0,016017^{*} \mathrm{x}+0.1217$ & 0.97 \\
\hline
\end{tabular}

* Significant at $\mathrm{p}<0.05 \%$ by the Scott_Knot. $* * \mathrm{R}^{2}$, coefficient of determination. 
The greatest peak of $\mathrm{K}$ release by the nepheline syenite was observed after 180 days of' incubation, at the dose of $40 \%$ of coffee husk, a fact observed for both extractors, citric acid solution and water (Figures $3 \mathrm{a}$ and $3 \mathrm{~b}$ ).

Potassium release for the mixtures of nepheline syenite with humic acid doses over time is shown if Figure 4 and the equations fitted to these data, in Table 3. Overall, a significant increase in the solubility of the potassium from nepheline syenite occurred as a function of humic acid dose.

Humic acid sample used in this study has $8.5 \%$ of $\mathrm{K}_{2} \mathrm{O}$, and this concentration of potassium was reflected in the final availability of the nutrient in each treatment, which can be confirmed by observing the data at the beginning of incubation.

The increase of potassium availability over time in the treatments is possibly related to organic acids and acidification generated by microorganisms which reacts with the rock, modifying its structure. Regarding the use of citric acid in the solubilization of potassium rocks, Max et al. (2010) gives a list of fungi capable of producing this acid, among them, are many belonging to the genus Aspergillus. Citric acid has the ability to acidify the medium, destabilizing the minerals present and possibly increasing the release of $\mathrm{K}_{2} \mathrm{O}$ (Lopes-Assad et al. 2006).

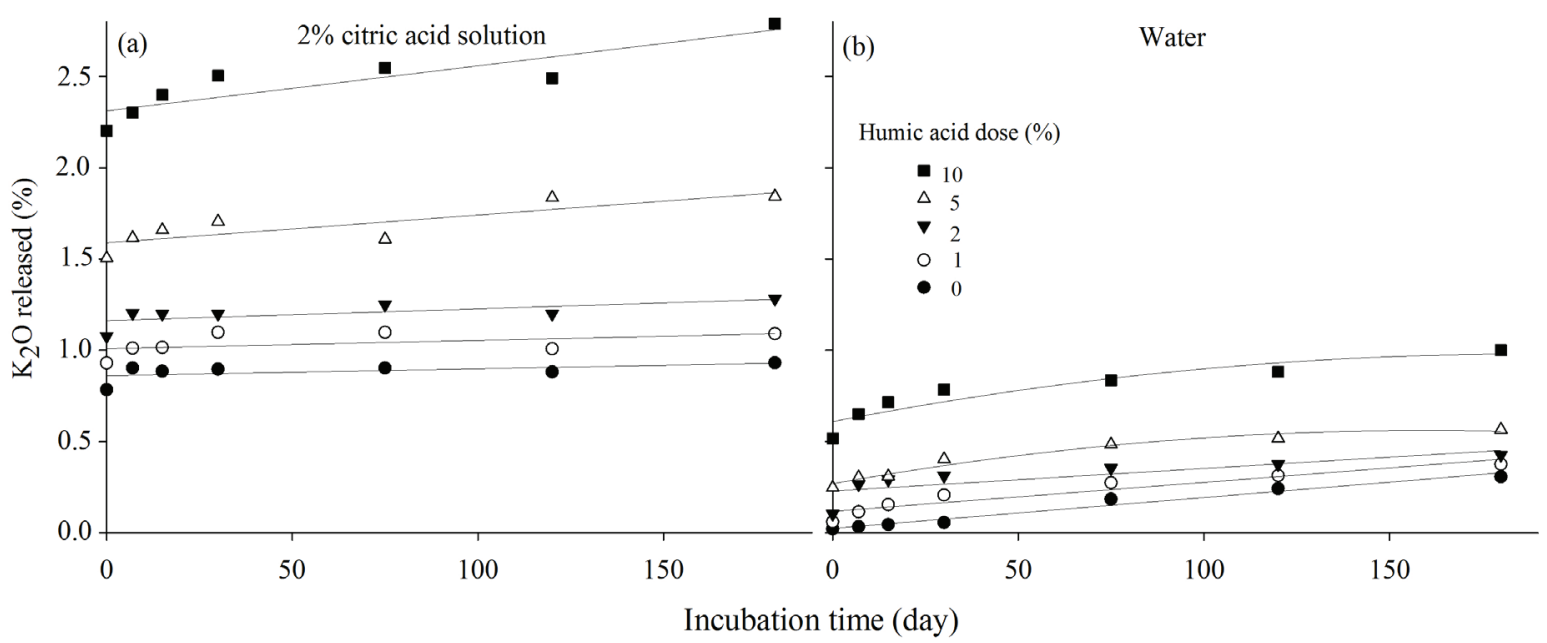

Figure 4: Potassium released by the nepheline syenite samples over time as a function of humic acid dose, with $\mathrm{K}$ extraction in: (a) citric acid solution, and (b) water.

Table 3: Mathematical equations fitted to the $\mathrm{K}$ released over time as a function of humic acid (HA) dose and $\mathrm{K}$ extraction with citric acid solution and water.

\begin{tabular}{|c|c|c|c|c|}
\hline \multirow{6}{*}{ 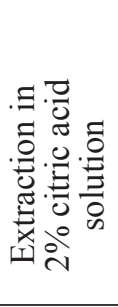 } & Figure & HA dose $(\%)$ & Equation & $\mathrm{R}^{2}$ \\
\hline & $4 \mathrm{a}$ & 0 & $y=0.000373 * x+0.86$ & 0.29 \\
\hline & $4 \mathrm{a}$ & 1 & $y=0.000446^{*} x+1.01$ & 0.23 \\
\hline & $4 \mathrm{a}$ & 2 & $y=0.000664 * x+1.16$ & 0.49 \\
\hline & $4 a$ & 5 & $\mathrm{y}=0.001519 * x+1.59$ & 0.69 \\
\hline & $4 a$ & 10 & $\mathrm{y}=0.002456^{*} \mathrm{x}+2.31$ & 0.78 \\
\hline \multirow{5}{*}{ 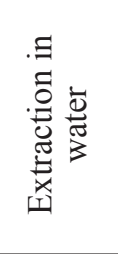 } & $4 \mathrm{~b}$ & 0 & $y=0.001684 * x+0.0249$ & 0.97 \\
\hline & $4 \mathrm{~b}$ & 1 & $y=0.001546 * x+0.1066$ & 0.89 \\
\hline & $4 \mathrm{~b}$ & 2 & $\mathrm{y}=0.001188 * \mathrm{x}+0.2190$ & 0.63 \\
\hline & $4 \mathrm{~b}$ & 5 & $y=-0.000009 * x^{2}+0.0031 * x+0.2709$ & 0.96 \\
\hline & $4 \mathrm{~b}$ & 10 & $y=-0.000014 * x^{2}+0.0046 * x+0.6021$ & 0.88 \\
\hline
\end{tabular}

* Significant at $\mathrm{p}<0.05 \%$ by the Scott-Knot test. ** $\mathrm{R}^{2}$, coefficient of determination.

Ciênc. Agrotec., Lavras, v. 39, n. 6, p. 553-564, nov./dez., 2015 
In line with this research, Han and Lee (2005) evaluated the action of the Bacillus megaterium in the solubilization of minerals such as mica, illite, and orthoclase, through production of organic acids and observed an increase in the availability of soluble potassium. Following a similar line, Lopes-Assad et al. (2006) found that acidification promoted by the fungus A. niger provides an increase in soluble potassium contained in some potassic silicate rocks. These studies provide similar results found by this work, indicating that, when organic substances are present, they have the potential to solubilize rock containing potassium minerals, however, the time factor may be a significant variable.
The mixture of nepheline syenite with citric acid provided an alteration of the soluble potassium content of the rock (Figure 5 and Table 4). It was observed that the doses $0,1,2,5$ and $10 \%$ of citric acid provided similar solubility (Figure 5a) when $2 \%$ citric acid solution was used to extract the $\mathrm{K}$ released. The $10 \%$ citric acid dose provided the greatest amount of $\mathrm{K}$ released by the rock. For water-soluble potassium (Figure 5b), the effect of the citric acid doses in the mixture with the rock was more evident. Effect of incubation time was also more evident when water was used to measure $\mathrm{K}$ solubilized; however, the means of the soluble potassium content in $2 \%$ citric acid were always greater than those observed when water was used to extract $\mathrm{K}$.

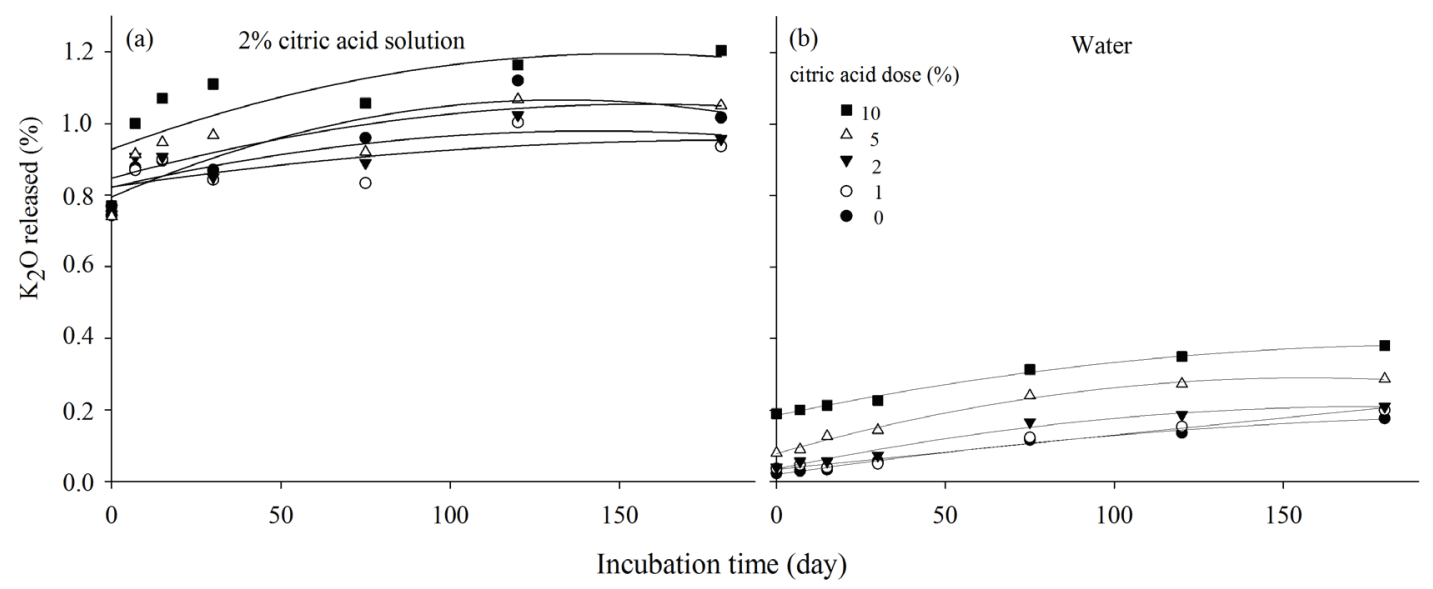

Figure 5: Potassium released by the nepheline syenite samples over time as a function of citric acid dose, with the $\mathrm{K}$ extraction in: (a) citric acid solution, and (b) water.

Table 4: Mathematical equations fitted to the $\mathrm{K}$ released over time as a function of citric acid dose and $\mathrm{K}$ extraction with citric acid solution and water.

\begin{tabular}{|c|c|c|c|c|}
\hline \multirow{6}{*}{ 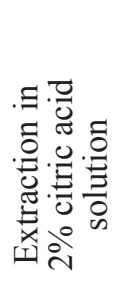 } & Figure & Citric acid dose $(\%)$ & Fitted mathematical equation & $\mathrm{R} 2 * *$ \\
\hline & $5 \mathrm{a}$ & 0 & $\mathrm{y}=-0.000015 * x 2+0.004086 * x+0.794745$ & 0.83 \\
\hline & $5 \mathrm{a}$ & 1 & $\mathrm{y}=-0.000007 * x 2+0.002051 * x+0.818013$ & 0.63 \\
\hline & $5 \mathrm{a}$ & 2 & $y=-0.000008 * x 2+0.002209 * x+0.821707$ & 0.56 \\
\hline & $5 \mathrm{a}$ & 5 & $y=-0.000008 * x 2+0.002628 * x+0.846981$ & 0.62 \\
\hline & $5 \mathrm{a}$ & 10 & $\mathrm{y}=0.000011 * \mathrm{x} 2+0.003502 * \mathrm{x}+0.92763$ & 0.60 \\
\hline \multirow{5}{*}{ 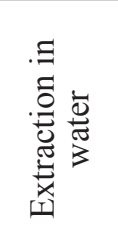 } & $5 b$ & 0 & $\mathrm{y}=-0.000003 * x 2+0.0011379 * x+0.019751$ & 0.99 \\
\hline & $5 b$ & 1 & $\mathrm{y}=0.000959 * x+0.034349$ & 0.98 \\
\hline & $5 b$ & 2 & $y=-0.000006 * x 2+0.001978 * x+0.035053$ & 0.98 \\
\hline & $5 b$ & 5 & $\mathrm{y}=-0.000006 * \mathrm{x} 2+0.001978 * \mathrm{x}+0.035053$ & 0.98 \\
\hline & $5 b$ & 10 & $\mathrm{y}=0.000005 * \mathrm{x} 2+0.001975 * \mathrm{x}+0.184909$ & 0.99 \\
\hline
\end{tabular}

* significant at $\mathrm{p}<0.05$ by the Scott - Knot test; $* * \mathrm{R}^{2}$, coefficient of determination. 


\section{Glauconite solubilization}

In general, there was a significant increase in the solubility of the potassium from glauconite by application of the organic matrix and with time of incubation. Among the organic matrices, it was observed that coffee husk was the one which provided the greatest potassium release in glauconite (Figure 6 and Table 5). This result may be associated with a greater soluble potassium content in coffee husks relative to the other organic matrices. Overall this contributed to a greater soluble $\mathrm{K}_{2} \mathrm{O}$ content of the mixture. It was also found that the greatest proportion of organic matrices with glauconite was the one which at all incubation times provided the greatest release of $\mathrm{K}_{2} \mathrm{O}$ in both extractants. In a similar line of research, Calazans et al. (2011) evaluated the effect of the composting glauconite with organic residues; these authors found little expressive gains in rock solubility and that part of the determined soluble potassium was from the organic matrix, similar to what we found in this study.

It was observed, in Figures $6 \mathrm{a}$ and $6 \mathrm{~b}$ that the $\mathrm{K}$ released by the mixture of glauconite rock with coffee husk followed the same trend of the treatment of nepheline syenite with humic acid (Figure 7 and Table 6). At the incubation beginning, in the treatment composed only of glauconite,

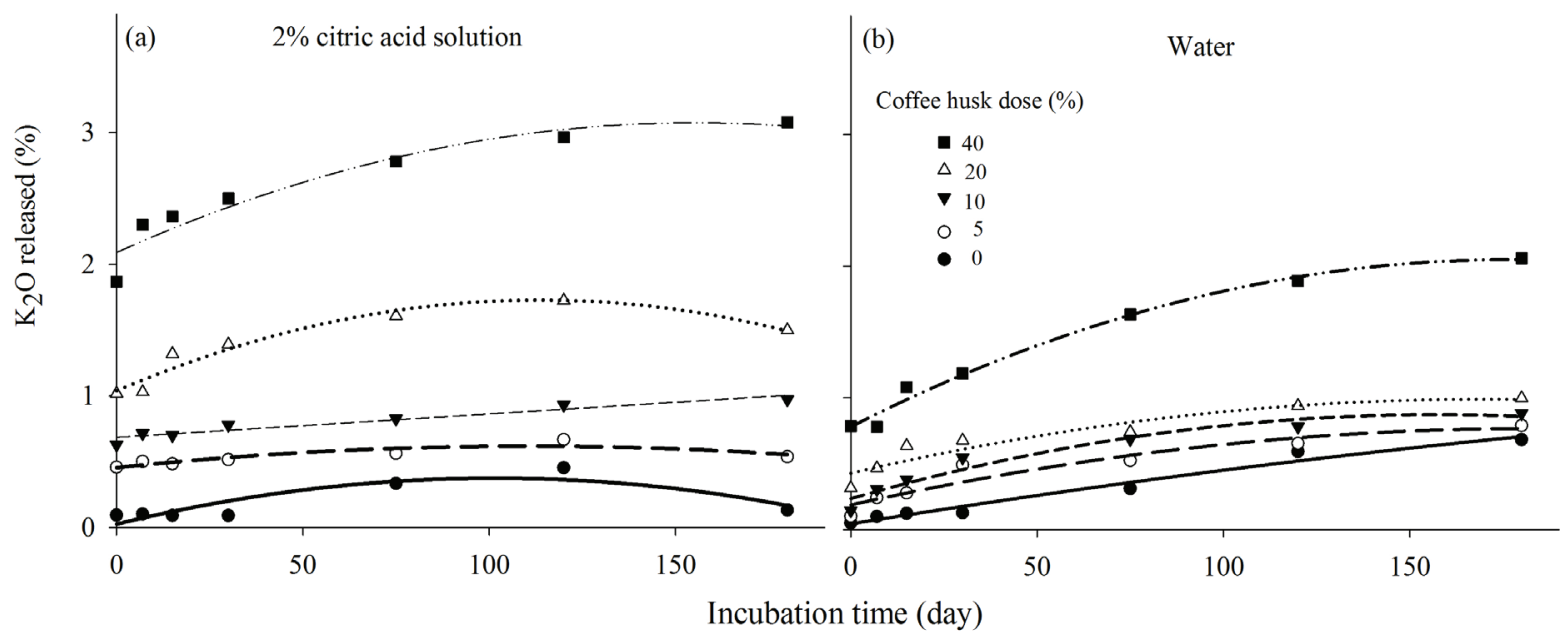

Figure 6: Potassium released by the modified glauconite samples over time as a function of coffee husk dose, with K extraction in: (a) citric acid solution, and (b) water.

Table 5: Mathematical equations fitted to the $\mathrm{K}$ released over time as a function of coffee husk dose and $\mathrm{K}$ extraction with citric acid solution and water.

\begin{tabular}{|c|c|c|c|c|}
\hline \multirow{6}{*}{ 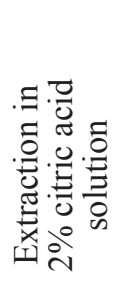 } & Figure & Coffee husk dose $(\%)$ & Fitted mathematical equation & $\mathrm{R}^{2}$ \\
\hline & $6 \mathrm{a}$ & 0 & $\mathrm{Y}=0.001136^{*} \mathrm{x}+0.99$ & 0.96 \\
\hline & $6 a$ & 5 & $y=-0.000014 * x^{2}+0.0034 * x+0.23$ & 0.73 \\
\hline & $6 \mathrm{a}$ & 10 & $y=-0.000010 * x^{2}+0.0028 * x+0.25$ & 0.68 \\
\hline & $6 a$ & 20 & $y=-0.000004 * x^{2}+0.0023 * x+0.28$ & 0.83 \\
\hline & $6 \mathrm{a}$ & 40 & $y=-0.000017 * x^{2}+0.0046 * x+0.28$ & 0.97 \\
\hline \multirow{5}{*}{ 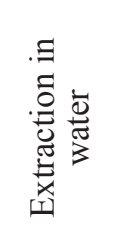 } & $6 \mathrm{~b}$ & 0 & $y=-0.000013 * x^{2}+0.0060 * x+0.0314$ & 0.98 \\
\hline & $6 \mathrm{~b}$ & 5 & $y=-0.000017 * x^{2}+0.0063 * x+0.1870$ & 0.92 \\
\hline & $6 \mathrm{~b}$ & 10 & $y=-0.000012 * x^{2}+0.0056 * x+0.2530$ & 0.88 \\
\hline & $6 \mathrm{~b}$ & 20 & $y=-0.000019 * x^{2}+0.0066 * x+0.4272$ & 0.88 \\
\hline & $6 b$ & 40 & $y=-0.000095 * x^{2}+0.0242 * x+0.7111$ & 0.87 \\
\hline
\end{tabular}

* Significant at $\mathrm{p}<0.05$ by the Scott-Knot test. ** $\mathrm{R}^{2}$, coefficient of determination. 
there was not much difference in the rock solubility among the two extractants used, citric acid and water, for the different sampling times. This is probably due to the low solubility that this rock has when exposed to solvents with low solubilizing capacity (Teixeira et al., 2012).

Data showed in Figure 8 and Table 7 represent the contents of potassium released by the glauconite rock incubated with citric acid at different doses. It can be observed that, in general, there was an increase in the soluble potassium content over incubation time and as the citric acid dose is increased up to $10 \%$. As the citric acid is typically acidic, the greatest dose of citric acid may have promoted a more efficient and aggressive degradation on the rock, which would explain the greater solubilization of potassium from the glauconite. Incubation time was also crucial, since this silicate rock is poorly soluble so that the $\mathrm{K}$ solubilization reactions occur very slowly over time.

Harley and Gilkes (2000) reported that release of potassium in rocks with low solubility mainly occurs by the action of organic and inorganic acids produced by biological activity, which act by releasing $\mathrm{H}^{+}$or complexant ligands. In addition, the very removal of soluble $\mathrm{K}$ by microbial absorption favors the release of potassium from minerals by increasing the concentration gradient during

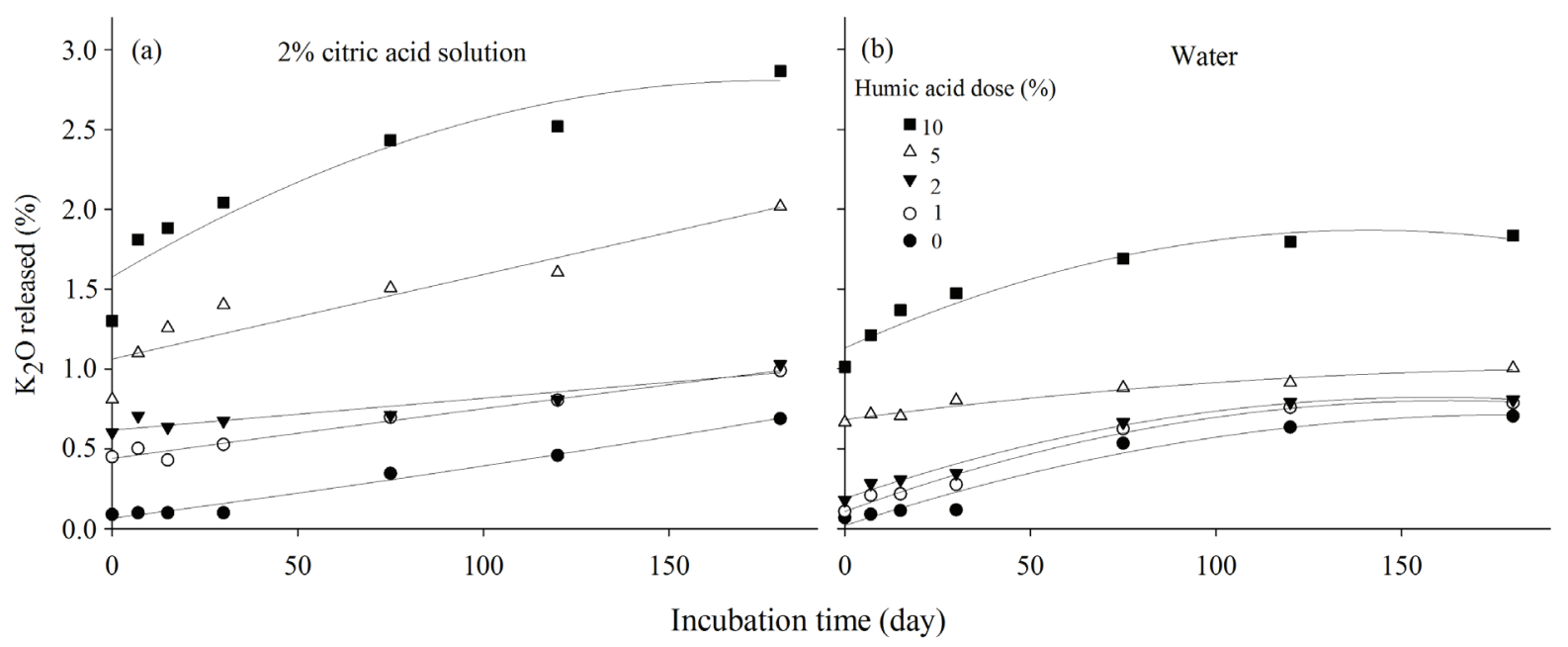

Figure 7: Potassium released by the modified glauconite samples over time as a function of humic acid dose, with $\mathrm{K}$ extraction in: (a) citric acid solution, and (b) water.

Table 6: Mathematical equations fitted to the $\mathrm{K}$ released over time as a function of humic acid (HA) dose and $\mathrm{K}$ extraction with citric acid solution and water.

\begin{tabular}{|c|c|c|c|c|}
\hline \multirow{6}{*}{ 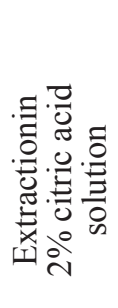 } & Figure & HA dose $(\%)$ & Equation & $\mathrm{R}^{2^{* *}}$ \\
\hline & $7 \mathrm{a}$ & 0 & $y=0.001136 * x+0.0988$ & 0.96 \\
\hline & $7 \mathrm{a}$ & 1 & $y=-0.000014 * x^{2}+0.003429 * x+0.2265$ & 0.73 \\
\hline & $7 \mathrm{a}$ & 2 & $y=-0.000011 * x^{2}+0.002936 * x+0.2592$ & 0.66 \\
\hline & $7 \mathrm{a}$ & 5 & $y=-0.000004 * x+0.002474 * x+0.2940$ & 0.83 \\
\hline & $7 \mathrm{a}$ & 10 & $y=-0.000019 * x^{2}+0.005120 * x+0.3175$ & 0.96 \\
\hline \multirow{5}{*}{ 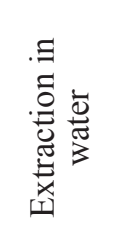 } & $7 \mathrm{~b}$ & 0 & $y=-0.000013 * x^{2}+0.005891 * x+0.071558$ & 0.97 \\
\hline & $7 \mathrm{~b}$ & 1 & $\mathrm{y}=-0.000011 * \mathrm{x}^{2}+0.005901 * \mathrm{x}+0.0832$ & 0.97 \\
\hline & $7 \mathrm{~b}$ & 2 & $y=-0.000015 * x^{2}+0.006612 * x+0.0854$ & 0.96 \\
\hline & $7 b$ & 5 & $y=-0.000014 * x^{2}+0.006440 * x+00.1118$ & 0.96 \\
\hline & $7 \mathrm{~b}$ & 10 & $y=-0.000016 * x^{2}+0.007167 * x+0.125806$ & 0.97 \\
\hline
\end{tabular}

* Significant at $\mathrm{p}<0.05$ by the Scott-Knot test. ** $\mathrm{R}^{2}$, coefficient of determination. 
hydrolysis reactions of minerals (Alexander, 1980, Harley and Gilkes, 2000). Hayes (1985) stressed that the organic substances of high molecular weight, such as humic substances, are less effective in dissolving minerals than those of low molecular weight, such as citric acid.

Considering all the sampling times evaluated, release of $\mathrm{K}$ by nepheline syenite has a similar pattern than that verified for modified glauconite. However, it was possible to conclude that the soluble $\mathrm{K}$ content of nepheline syenite is greater than that released by the modified glauconite, indicating that rocks with different compositions or types of formation can have different weathering rates when mixed with different organic matrices.

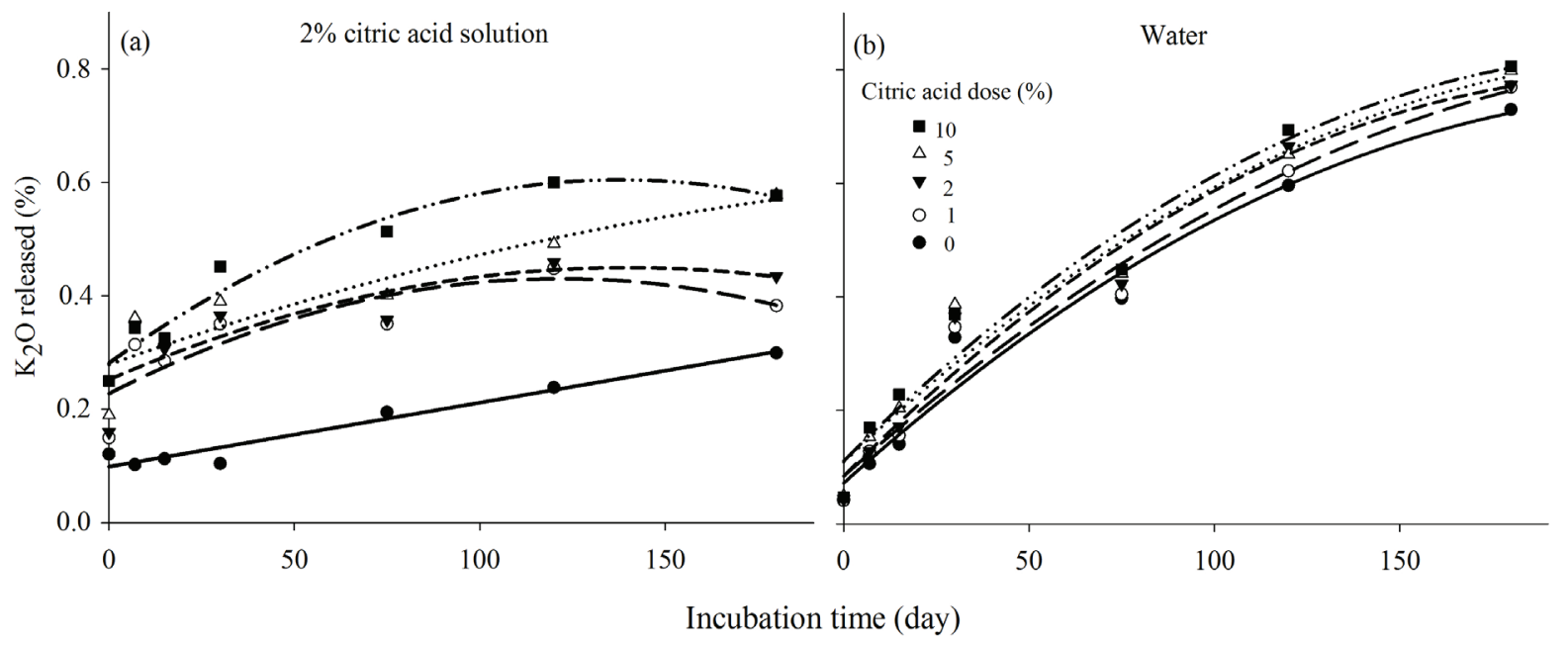

Figure 8: Potassium released by the modified glauconite samples over time as a function of citric acid dose, with $\mathrm{K}$ extraction in: (a) citric acid solution, and (b) water.

Table 7: Mathematical equations fitted to the $\mathrm{K}$ released over time as a function of citric acid dose and $\mathrm{K}$ extraction with citric acid solution and water.

\begin{tabular}{|c|c|c|c|c|}
\hline \multirow{6}{*}{ 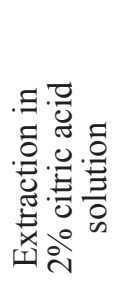 } & Figure & Citric acid dose $(\%)$ & Equation & $\mathrm{R}^{2^{* *}}$ \\
\hline & $8 \mathrm{a}$ & 0 & $y=-0.000038 * x^{2}+0.0074 * x+0.0289$ & 0.77 \\
\hline & $8 \mathrm{a}$ & 1 & $y=-0.000038 * x^{2}+0.0072 * x+0.3985$ & 0.82 \\
\hline & $8 \mathrm{a}$ & 2 & $\mathrm{y}=0.001995 * \mathrm{x}+0.6164$ & 0.88 \\
\hline & $8 \mathrm{a}$ & 5 & $\mathrm{y}=0.005278 * \mathrm{x}+1.0642$ & 0.86 \\
\hline & $8 \mathrm{a}$ & 10 & $y=-0.000039 * x^{2}+0.0137 * x+1.57$ & 0.91 \\
\hline \multirow{5}{*}{ 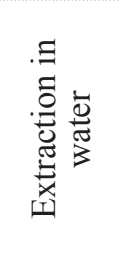 } & $8 \mathrm{~b}$ & 0 & $y=-0.000021 * x^{2}+0.007598 * x+0.0204$ & 0.96 \\
\hline & $8 \mathrm{~b}$ & 1 & $y=-0.000027 * x^{2}+0.008589 * x+0.1053$ & 0.99 \\
\hline & $8 b$ & 2 & $y=-0.000025 * x^{2}+0.0080 * x+0.1869$ & 0.99 \\
\hline & $8 \mathrm{~b}$ & 5 & $y=-0.000007 * x^{2}+0.0031 * x+0.6840$ & 0.97 \\
\hline & $8 \mathrm{~b}$ & 10 & $y=-0.000037 * x^{2}+0.0104 * x+1.1317$ & 0.95 \\
\hline
\end{tabular}

\footnotetext{
* Significant at $5 \%$ probability by the Scott-Knot test. $* * \mathrm{R}^{2}$, coefficient of determination.
} 


\section{CONCLUSIONS}

Soluble K contents, regardless of the K rockorganic matrix mixture incubated, are greater when $\mathrm{K}$ is extracted with the $2 \%$ citric acid solution instead of water. The right choice of the $\mathrm{K}$ test is relevant, based on the fact that citric acid can assess the availability of $\mathrm{K}$ to plants.

Low grade $\mathrm{K}$ rocks have low and variable levels of soluble $\mathrm{K}$, whose contents in the two potassic rocks depends on the analytical protocol employed and are in the range of $1.3-1,7 \%$ for the nepheline syenite samples, and from 1.1 to $3.3 \%$, for the modified glauconite.

Regardless of the organic matrix and its dose investigated, the release of $\mathrm{K}$ is higher when the nepheline syenite samples are incubated compared to the modified glauconite.

As the incubation time is increased, the amount of solubilized $\mathrm{K}$ is higher, regardless of the different $\mathrm{K}$ rock-organic matrix mixtures tested.

The organic matrices have different ability to weather the incubated potassic rocks, with the following decreasing order of solubilization capacity: coffee husk $>$ humic acid $>$ citric acid. Amounts of $\mathrm{K}$ released in the different sampling times rely also on the dose of the organic matrix mixed with the two rocks investigated.

\section{ACKNOWLEDGEMENTS}

The authors wish to thank the National Council for Scientific and Technological Development for supporting (process 308592/2011-5) part of the research costs and for providing scholarships. We also thank the anonymous reviewers for their comments and suggestions to edit the manuscript. We are also in debt with Dr. Fábio S. Highashikawa, for providing the coffee husk sample.

\section{REFERENCES}

ABBASI, M. K.; MUSA, N.; MANZOOR, M. Phosphorus release capacity of soluble $\mathrm{P}$ fertilizers and insoluble rock phosphate in response to phosphate solubilizing bacteria and poultry manure and their effect on plant growth promotion and P utilization efficiency of chilli (Capsicum annuum L.). Biogeosciences Discussion, 12:1839-1873, 2015.

ADESANWO, O. O.; ADETUNJI, M. T.; DIATTA, $\mathrm{S}$. Effect of legume incorporation on solubilization of Ogun phosphate rock on slightly acidic soils in SW Nigeria, J. Plant Nutrition and Soil Science, 175:377384, 2012.
ALEXANDER, M. Introduccion a la Microbiología

del suelo. México: AGT, 1980. 491p.

ALLOUSH, G. A. Dissolution and effectiveness of phosphate rock in acidic soil amended with cattle manure. Plant Soil, 251:37-46, 2003.

ANDRADE, P. M. et al. Efeito da adição de sienito nefelínico na sinterização de argila caulinítica.

Cerâmica, 51:361-370, 2005.

BALDOTTO, M. A. et al. Desempenho inicial do abacaxizeiro e aproveitamento do fosfato natural aplicado com compostos orgânicos nas axilas foliares.

Revista Ceres, 58(3):393-401, 2011.

CALAZANS, G. M. et al. Dinâmica da atividade das fosfatases ácida e alcalina em sistema de compostagem de resíduos agrícolas associados a rochas. Cadernos de Agroecologia, 6(2):1-6, 2011.

CHEN, J. Development and utilization of potassiumbearing resource and their prospects. Geology of Chemical Minerals, 22:58-64, 2000.

COMPANHIA NACIONAL DE

ABASTECIMENTO - CONAB. 2015. Safras; séries históricas. Avaliable in: $<$ http://www.conab. gov.br/conteudos.php? $\mathrm{a}=1252 \& \mathrm{t}=2 .>$ Access in: January 5, 2015.

FERREIRA, D. F. Sisvar: a computer statistical analysis system. Ciência e Agrotecnologia, 35(6):1039-1042, 2011.

HAN, H. S.; LEE, K. D. Phosphate and potassium solubilizing bacteria effect on mineral uptake, soil availability and growth of eggplant. Research Journal of Agriculture and Biological Sciences, 1:176-180, 2005.

HARLEY, A. D.; GILKES, R. J. Factors influencing the release of plant nutrient elements from silicate rock powders: A geochemical overview. Nutrient Cycling in Agroecosystems, 56:11-36, 2000.

HAYES, M. H. B. Extraction of humic substances from soil. In: AIKEN, G. R. et al. (Eds.). Humic substances in soil, sediment, and water. New York: John Wiley \& Sons, 1985. p.329-362. 
HIGASHIKAWA, F. S.; SILVA, C. A.; BETTIOL, W. Chemical and physical properties of organic residues. Revista Brasileira de Ciência do Solo, 34(5):17421752, 2010.

INTERNATIONAL CENTRE FOR DIFFRACTION DATA - ICDD. Powder Diffraction Files, Card No. 04-0806. Database Edition, 2006.

LIU, D. et al. Degradation of potassium rock by earthworms and responses of bacterial communities in its gut and surrounding substrates after being fed with mineral. PLoS ONE, 6(12):1-17, 2011.

LOPES-ASSAD, M. L. et al. The solubilization of potassium-bearing rock poder by Aspergillus niger in small-scale batch fermentations. Canadian Journal of Microbiology, 56:598-605, 2010.

Solubilização de pó-de-rocha por Aspergillus niger. Espaço \& Geografia, 9(1):1-17, 2006.

MAX, B. et al. Biotechnological production of citric acid. Brazilian Journal of Microbiology, 41:862-875, 2010.

MINISTÉRIO DA AGRICULTURA, PECUÁRIA E ABASTECIMENTO - MAPA. Instrução Normativa $\mathrm{n}^{\circ} 28$, de 27 de julho de 2007. Aprova os métodos analíticos oficiais para fertilizantes minerais, orgânicos, organominerais e corretivos, disponíveis na Coordenação-Geral de Apoio Laboratorial - CGAL/ DAS/MAPA, na Biblioteca Nacional de Agricultura - BINAGRI e no sítio do Ministério da Agricultura, Pecuária e Abastecimento. Diário Oficial da República Federativa do Brasil, 31 jul. 2007. Seção 1, p. 11.

NASCIMENTO, M.; LOUREIRO, F. E. L. Rochas silicáticas como fontes minerais alternativas de potássio para a agricultura. In: Centro de tecnologia mineral ministério da ciência e tecnologia: Rochas minerais industriais: usos e especificações. Rio de
Janeiro, RJ: CETEM, 2008. cap.9. Available in: <http:// www.cetem.gov.br/publicação </CTs/CT2008-161-00. pdf $>$. Access in: August 19, 2014.

PIZA, P. A. et al. Verdete da região do Cedro de Abaeté (MG) como fonte alternative de potássio. Geociências, 30(3):345-356, 2011.

SALEEM, M. M.; ARSHAD, M.; YASEEN, M. Effectiveness of various approaches to use rock phosphate as a potential source of plant available $\mathrm{P}$ for sustainable wheat production. International Journal of Agriculture and Biology, 15:223-230, 2013.

SILVA, D. R. G. et al. Characterization and nutrient release from silicate rocks and influence on chemical changes in soil. Revista Brasileira de Ciência do Solo, 36(3):951-962, 2012a.

SILVA, A. A. S. et al. Caracterização do glauconita de cedro do Abaeté para o desenvolvimento de um material com liberação controlada de potássio. HOLOS, 5:4251,2012 b.

STEVENSON, F. J. Humus chemistry; genesis, composition, reactions. New York: John Wiley \& Sons, 2004. $496 \mathrm{p}$.

STRAATEN, P. V. Farming with rocks and minerals: challenges and opportunities. Anais da Academia Brasileira de Ciências, 78(4):731-747, 2006.

TEIXEIRA, A. M. S. et al. Avaliação da rocha sienito nefelínico como fertilizante alternativo de potássio.

HOLOS, 5:21-33, 2012.

THEODODO, S. H. et al. Experiências de uso de rochas silicáticas como fonte de nutrientes. Espaço e Geografia, 9(2):263-292, 2006.

ZOCA, S. M. et al. Coffee processing residues as a soil potassium amendment. International Journal of Recycling of Organic Waste in Agriculture, 3(4):155165, 2014. 